\title{
Impact of wastewater from the rural commune of Jmaa Moulblad on the physico-chemical quality of the waters of the Grou River (Rabat region, Morocco)
}

\author{
Karim ARIFI ${ }^{1,2 ; *}$, Latifa TAHRI ${ }^{2}$, Abdallah EL ABID ${ }^{4}$, Fatima Zahra HEFIANE ${ }^{2}$, \\ Souad ELBLIDI ${ }^{2}$, Ahmed YAHYAOUI ${ }^{3}$ and Mohammed FEKHAOUI ${ }^{2}$ \\ 1, 3 University Mohammed V - Faculty of Science, Ibn Battuta Av, PB : 1040 Agdal, Rabat. \\ 2, University Mohammed V - Scientific Institute, Ibn Battuta Av, PB : 703 Agdal, Rabat. \\ 4 National Institute of Hygiene, Hydrology and toxicology Laboratory of the Environmental and \\ Industrial Hygiene, Ibn Battuta Av, Agdal, Rabat.
}

\begin{abstract}
The Grou River is one of the main rivers that feed the reservoir of the Sidi Mohammed Ben Abdellah (SMBA) dam in Morocco. However, this river is particularly threatened by the pollution problem. It is in this context that this study aims to study the effect of wastewater from the rural commune of Jmaa Moulblad on the physicochemical quality of the waters of this river. We analyzed 11 physicochemical parameters $\left(\mathrm{T}^{\circ}\right.$ of area, $\mathrm{T}^{\circ}$ of water, $\mathrm{pH}, \mathrm{EC}, \mathrm{mV}, \mathrm{Sal}$, TDS, BOD, COD, SS and TOC), with a monthly frequency since the month of December 2014 until November 2015. The results obtained show a worrying situation of the state of this watercourse. To remedy this problem, we recommend pre-treatment of wastewater before discharge and the implementation of a management plan and sustainable management of the Grou River watershed.

Keywords : Pollution, wastewater, physicochemical, development, SMBA dam, Jmaa Moulblad, Morocco.
\end{abstract}

"Karim ARIFI : E-mail: arifi_karim@ hotmail.com 


\section{Introduction}

Water is an indispensable resource for life. It deserves special attention in view of the dangers to which it is subjected by human activities (urban discharges, industrial activities, agriculture, etc.) [1]. These activities tend to diminish the potential of good quality water resources [2]. But also, have a negative impact on the health of the population, the uses of water (water abstraction, bathing, etc.) and subsequently compromises socio-economic development $[3,4]$

In Morocco, a country with a semi-arid climate, the water potential is relatively limited and uncertain [5]. This potential is affected by the pollution problem in all regions of the kingdom, especially in the Rabat region, following a growing population increase, which has almost doubled in recent years and the continued development of the sector industrial and agricultural.

At the level of the rural commune of Jmaa Moulblad, located a few kilometers from the reservoir of the Sidi Mohammed Ben Abdellah dam (SMBA), the Grou River plays a very important role in the region; its waters are used in livestock watering, the production of drinking water, bathing and other activities of the local population. In recent years, the region has experienced rapid urbanization and a very significant development of agriculture and industry. This situation is accompanied both by a very high demand for water and by the increase in discharges of wastewater discharged without any prior treatment and also the degree of pollution of the surface waters, in particular those of the Grou River.

It is in this context that this study aims to evaluate the impact of wastewater from the rural commune of Jmaa Moulblad on the physicochemical quality of the waters of the Grou River to remedy this problem. Several water quality parameters were measured and analyzed $\left(\mathrm{T}^{\circ}\right.$ of area, $\mathrm{T}^{\circ}$ of water, $\mathrm{pH}, \mathrm{EC}, \mathrm{mV}$, Sal, TDS, BOD, COD, SS and TOC), since the month from December 2014 until November 2015 with a monthly frequency.

\section{Materials and Methods}

\subsection{Study site and sampling stations}

This study was conducted at the rural commune of Jmaa Moulblad (Rabat region in Morocco). Two sampling stations were selected on the bed of the Grou River (Figure 1).

$>$ Station $\mathrm{S}_{1}$ : Located upstream, has been chosen as the reference point.

$>$ Station $\mathrm{S}_{2}$ : Located immediately downstream after the confluence zone with wastewater from the rural commune of Jmaa Moulblad without any prior treatment.

\subsection{Sampling and analysis}

Sampling is done once a month (December 2014- November 2015). The water sampling is carried out in 1.51 plastic bottles, previously rinsed with water from each of the selected stations. At each sampling, the temperature of the area, the temperature of the water, the electrical conductivity $(\mathrm{CE})$, the potential Hydrogen $(\mathrm{pH})$, the redox potential $(\mathrm{mV})$, the Salinity (Sal) and the total hardness (TDS) were measured in situ in the field using portable waves. The other physicochemical parameters are measured later, immediately upon our return to the laboratory. The transport is done in a cooler at low temperature $\left(+4^{\circ} \mathrm{C}\right)$. The analytical techniques followed are those described by AFNOR [7] and Rodier [8]. 


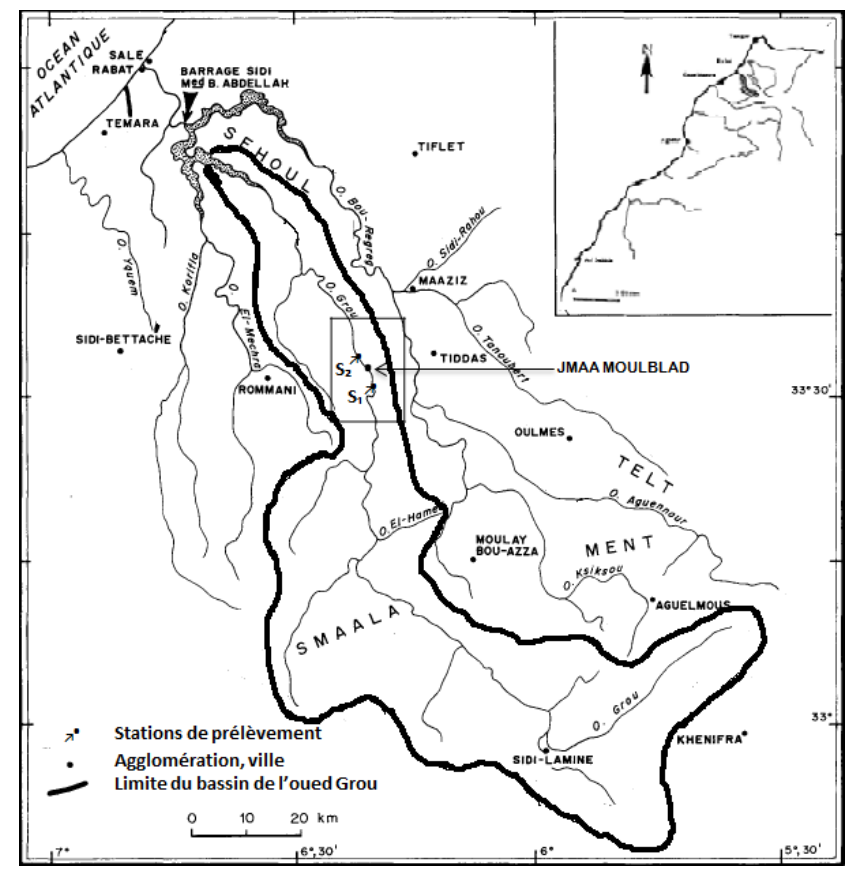

Fig. 1. Location of sampling stations (Source: QNINBA 1988 Slightly modified).

\section{Results and Discussion}

\subsection{Air temperature $\left({ }^{\circ} \mathrm{C}\right)$}

The air temperatures measured in this study show markedly irregular spatial and temporal variations (Figure 2a). The lowest were measured during the winter period, with a minimum of $9^{\circ} \mathrm{C}$ recorded in both stations in December 2014 and January 2015, while the highest were measured during the summer, with a maximum of $38^{\circ} \mathrm{C}$ recorded in July 2015 at the station $\mathrm{S}_{2}$.

\subsection{Water Temperature $\left({ }^{\circ} \mathrm{C}\right)$}

The results of the water temperature obtained in this study show very large spatio-temporal variations (Fig 2b), generally hot in summer (maximum $28.6^{\circ} \mathrm{C}$ ) and cold in winter (minimum $10,4^{\circ} \mathrm{C}$ ). It is related to local conditions (climate, duration of sunshine, flow) [9].

In conclusion, the temperature of the water closely follows that of the atmospheric temperature in relation to the climate of the region. According to the Moroccan standard of surface water [10], the temperatures measured in the two stations belong to the middle class.

\subsection{Hydrogen potential $(\mathrm{pH})$}

The results obtained in this study show seasonal variations in $\mathrm{pH}$ between 7.69 and 9.03 (Figure 2c). This $\mathrm{pH}$ is relatively alkaline due to the effect of the discharges that this stream receives throughout its course and in particular in the rural commune of Jmaa Moulblad. The low values are recorded in winter because of the acidity of the precipitations while the highest values are recorded in the summer period because of the bacterial activity which degrades the abundant organic matter at the bottom and because of the activity photosynthetic algae, our results align with those of [11] in the waters of the Boufkrane River. 
In conclusion, the spatio-temporal variations in the $\mathrm{pH}$ of the waters of the Grou River are characterized by an alkaline $\mathrm{pH}$ of over 8.0 during all months except for (December, January and February), thus exceeding the value threshold recommended by the World Health Organization (WHO) which should be less than 8. According to [12] water that has a $\mathrm{pH}$ of more than 8.0 is difficult to treat.

\subsection{Electrical conductivity $(\mu \mathrm{S} / \mathrm{cm})$}

The electrical conductivity reflects the degree of global mineralization, and provides information on the salinity rate [13].

The results obtained in this study fluctuate between $454 \mu \mathrm{S} / \mathrm{cm}$ in March and 1080 $\mu \mathrm{S} / \mathrm{cm}$ in May, thus showing very large spatio-temporal variations (Figure $2 \mathrm{~d}$ ). These values remain below the Moroccan standard for surface water $(2700 \mu \mathrm{s} / \mathrm{cm})$ [10]. This made it possible to classify the water quality of this zone as good to medium. This mineralization is much lower than that shown in some Moroccan rivers such as, the Khuan River [14], the Tizguit River [15] and the Boufekrane River [16].

\subsection{The redox potential $(\mathrm{mV})$}

In our study, the values of the redox potential vary between a minimum of $-148 \mathrm{mV}$ in $\mathrm{S}_{2}$ and a maximum of $-67 \mathrm{mV}$ in $\mathrm{S}_{1}$, thus show very significant spatio-temporal variations. The lowest levels were recorded during the summer, while the highest levels were recorded during the winter (Figure $2 \mathrm{e}$ ). While going from the station $S_{1}$ to the station $S_{2}$, a reduction in the redox values is observed. This could explain the fact that this river receives directly the wastewater generated by the rural commune of Jmaa Moulblad without any prior treatment, thus causing the decrease of the oxygen contents and consequently the deterioration of the quality of the water. This finding is consistent with [17]; the high redoxes coincide with the high oxygen levels while the low redoxes are in agreement with the lack of oxygen.

In conclusion, the values of the redox potentials obtained clearly show the polluting effect of the wastewater at the station $\mathrm{S}_{2}$.

\subsection{Salinity (Sal)}

In this study, the salinity values vary between $0.1 \mathrm{~g} / 1$ in December $\left(\mathrm{S}_{1}\right)$ and $0.5 \mathrm{~g} / 1$ in May and October $\left(S_{1}\right.$ and $\left.S_{2}\right)$, thus show different spatio-temporal variations (fig. $2 \mathrm{~F}$ ). This could be explained by the effect of the wastewater coming from the rural commune of Jmaa Moulblad without any prior treatment and by the effect of the weak slope which makes the speed of the current almost nil by inhibiting the phenomenon of self-purification. On the other hand by the effect of strong evaporation in the absence of any precipitation promotes the elevation of salinity in summer and by the nature of the soil crossed and the origin of water. According to [18]; Salinity is mainly related to the origin of the waters.

In addition, there is a high salinity in the waters of both stations with a gradient increasing while going downstream.

\subsection{Total Dissolved Solids (TDS)}

The total dissolved solids of the water vary at the level of the study area according to the same gradient as that of salinity, thus showing very large spatio-temporal fluctuations. Values range from $199 \mathrm{mg} / \mathrm{l}$ in December to $570 \mathrm{mg} / \mathrm{l}$ in May (Figure $2 \mathrm{~g}$ ). Indeed, the total dissolved solids is all the higher as we move from $S_{1}$ to $S_{2}$. This translates, once again, the effect of the lands crossed and the wastewater, provoking the precipitation of $\mathrm{Ca}++$ and $\mathrm{Mg}++$ cations. In addition, there is a high total dissolved solids (TDS) which reflects a state of pollution of the waters of the Grou River. 


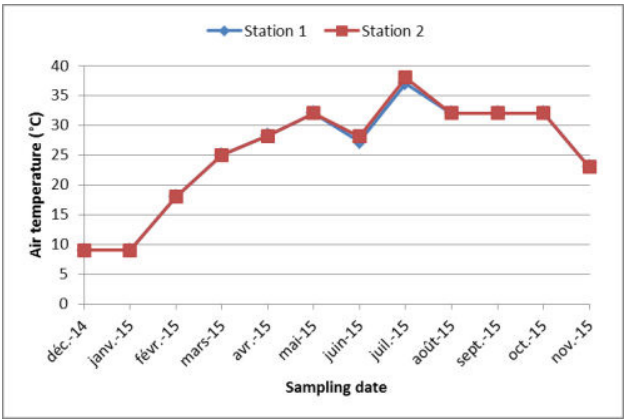

(a)

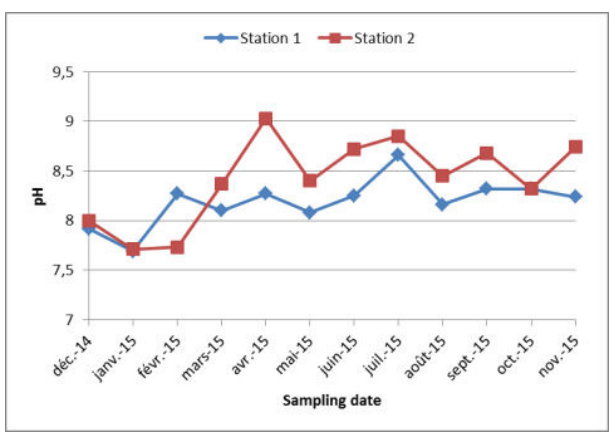

(c)

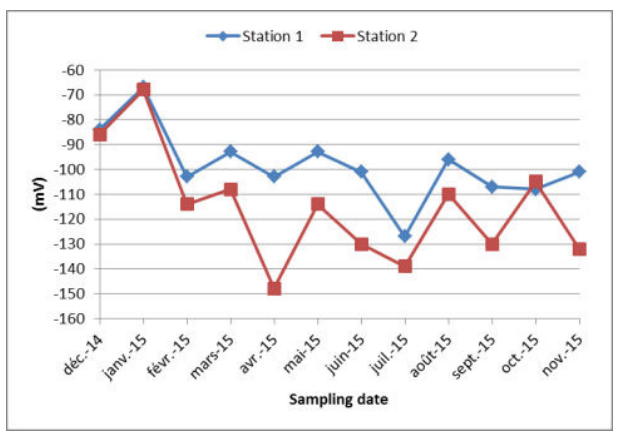

(e)

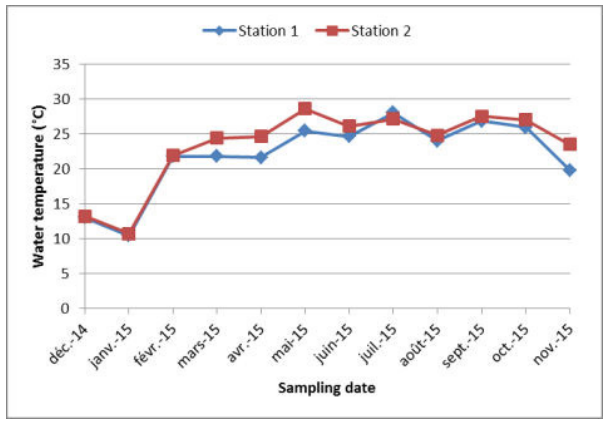

(b)

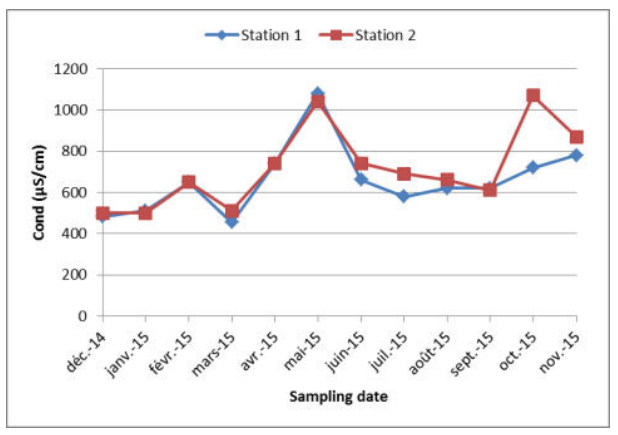

(d)

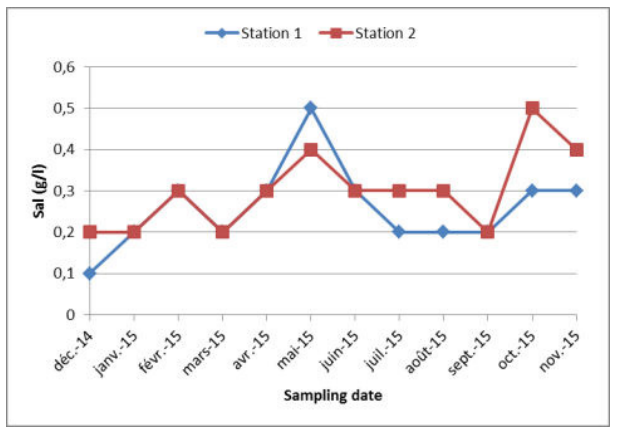

(f) 


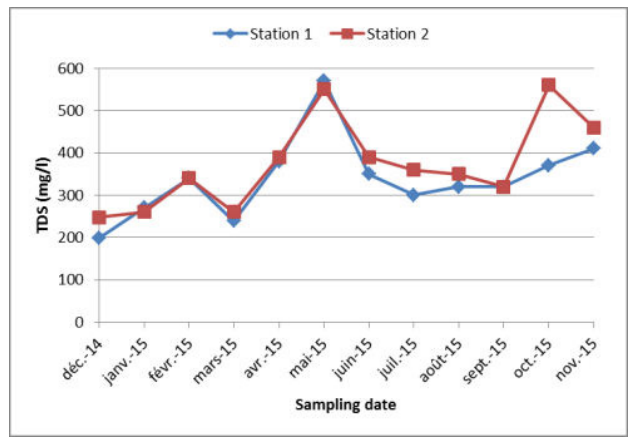

(g)

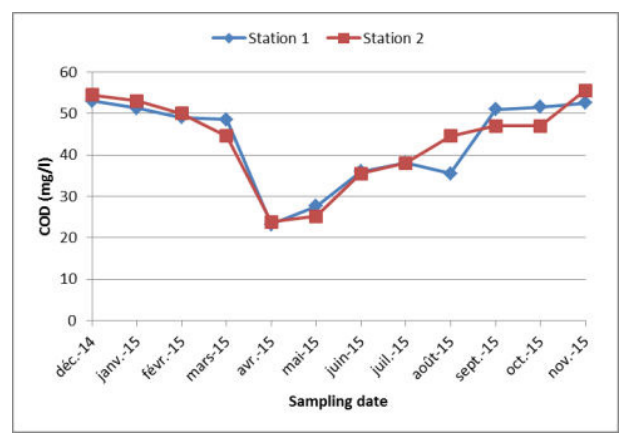

(i)

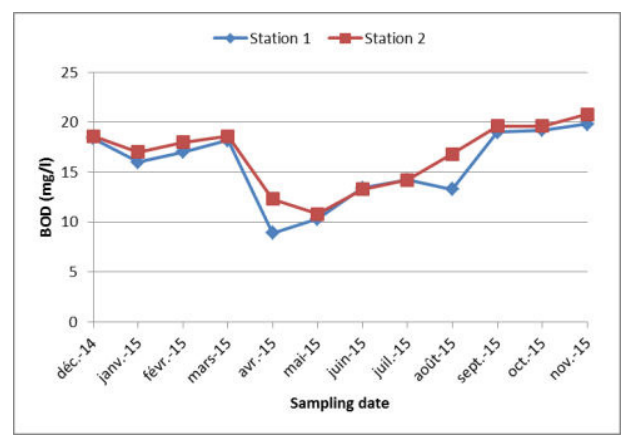

(h)

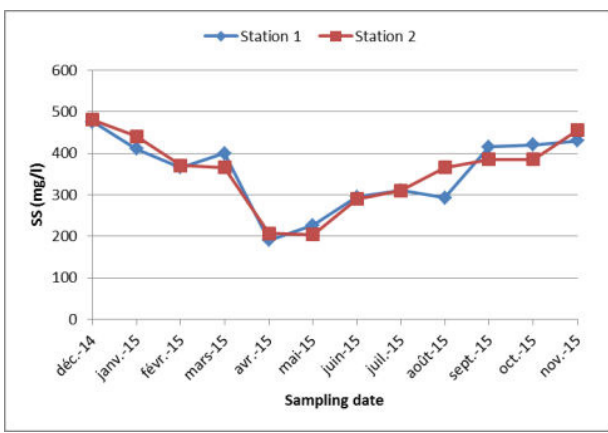

(j)

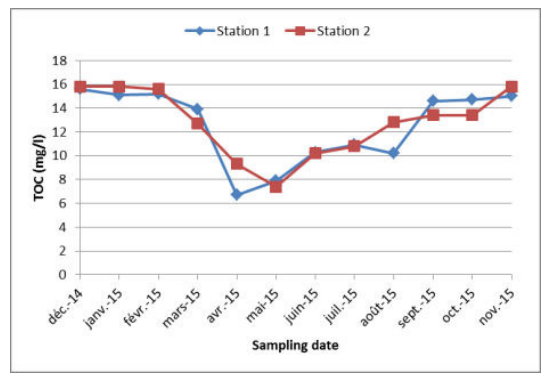

(k)

Fig. 2. Spatio-temporal variation of various physicochemical parameters of the Grou River under the effect of wastewater from the rural commune of Jmaa Moulblad

\subsection{Biochemical Oxygen Demand (BOD)}

In our study, the BOD contents ranged between $8.90 \mathrm{mg} / \mathrm{l}\left(\mathrm{S}_{1}\right)$ in April and $20.8 \mathrm{mg} / \mathrm{l}\left(\mathrm{S}_{2}\right)$ in November, thus showing very significant spatio-temporal variations (Fig $2 \mathrm{~h}$ ). In fact, at the level of the $S_{1}$ station, the BOD contents are between $8.90 \mathrm{mg} / \mathrm{l}$ and $19.8 \mathrm{mg} / \mathrm{l}$ with an average of $15.63 \mathrm{mg} / \mathrm{l}$ which exceeds the guide value. This can be explained by the fact that as the river flows downstream, it receives more and more water from anthropogenic activities in charge of organic matter. Then, at the $S_{2}$ station the levels are slightly increased, due to the effect of wastewater from the rural commune of Jmaa Moulblad without any prior treatment.

In conclusion, the average values of BOD, obtained both in summer and in winter, remain above the guideline value of European and Moroccan standards (NMES) (from 6 to 
$10 \mathrm{mg} / \mathrm{l})$. As a result, the waters of both stations are classified in the category of poor quality water.

\subsection{The Chemical Oxygen Demand (COD)}

In this study, the recorded COD content is between $23.2 \mathrm{mg} / \mathrm{l}\left(\mathrm{S}_{1}\right)$ in April and $55.5 \mathrm{mg} / \mathrm{l}$ $\left(S_{2}\right)$ in November, thus showing very large spatio-temporal variations (figure $2 \mathrm{i}$ ). In winter, the values obtained in the two stations are higher than those measured in the summer period, this could be explained by the leaching and the inflow of runoff water. Moreover, in summer, the levels recorded at station $S_{1}$ are slightly lower than those recorded at station $\mathrm{S}_{2}$. This could be explained by the effect of wastewater from the rural commune of Jmaa Moulblad.

In conclusion, the averages of the COD content recorded at the two stations in the downstream part of the Grou River slightly exceed the Moroccan standard of $40 \mathrm{mg} / \mathrm{l}$ [10]. As a result, the waters of both stations are classified as medium quality waters.

\subsection{Suspended matter (SS)}

In this study, suspended matter (SS) levels, ranging from $190 \mathrm{mg} / \mathrm{l}\left(\mathrm{S}_{1}\right)$ in April to $480 \mathrm{mg} / \mathrm{l}$ $\left(S_{2}\right)$ in December, show very large spatio-temporal variations (Figure $2 \mathrm{j}$ ). The values obtained in winter are higher than those measured in summer. This observation is in agreement with other studies made on other rivers such as, the Moulouya River in Morocco [19], the Mellah River in Algeria [20], and the Senegal River [21]. Indeed, in winter, high levels are the result of a sudden hydrological event (flood), whose load in SS is attributed to an intense erosion of the watershed. In summer, the concentrations of SS are lower in station $S_{1}$ than in station $S_{2}$, due to the effect of wastewater discharges from the rural commune of Jmaa Moulblad.

In conclusion, the SS values recorded at the two stations far exceed the Moroccan standard for surface water quality [10] set at $50 \mathrm{mg} / \mathrm{l}$. As a result, the waters of this area of the Grou River are classified in the category of poor quality water.

\subsection{Total Organic Carbon (TOC)}

In our study, TOC levels ranging from $6.7 \mathrm{mg} / \mathrm{l}\left(\mathrm{S}_{1}\right)$ in April to $15.8 \mathrm{mg} / \mathrm{l}\left(\mathrm{S}_{2}\right)$ in January, December and November, show significant spatial and temporal variations (Fig. $12 \mathrm{k}$ ).

In winter, the values obtained are higher than those measured in summer, this can be explained by the inputs of runoff and leaching. In addition, there is a high concentration of TOC that reflects a state of pollution of the waters of the Grou River. This finding is consistent with [22]; which explained the high TOC load of the lower Loukkos estuary ( 8.33 and $19.96 \mathrm{mg} / \mathrm{l})$, in the upstream-downstream direction through intense erosion of the watershed, following brutal storm rains and contributions of erosion and pollution.

In conclusion, the average TOC values recorded at the two stations of the Grou River, $12.5 \mathrm{mg} / \mathrm{l}$ in $\mathrm{S}_{1}$ and $12.7 \mathrm{mg} / \mathrm{l}$ in $\mathrm{S}_{2}$, are higher than those recorded at Bou Regreg River 7,8 $\mathrm{mg} / \mathrm{l} ;$ [23] and those recorded at the Port Jackson Estuary $4.54 \mathrm{mg} / \mathrm{l}$; [24]. This increase can also be attributed to the effect of the discharges that this stream receives along its course and to the effect of wastewater from the rural commune of Jmaa Moulblad at the station $\mathrm{S}_{2}$.

\section{Conclusion}

In the light of the results obtained in this work, there is a deterioration of the water quality of the Grou River at the level of the study area, particularly at the station $\mathrm{S}_{2}$ located downstream of the rural commune of Jmaa Moulbad generates very large quantities of wastewater and discharges them without any prior treatment.

The results obtained vary widely according to physicochemical parameters, seasons and stations. The analyzes revealed levels that exceed Moroccan standards for surface water. The causes result from the non-responsible behavior of the population who live along this 
watercourse, the exploitation of sands, the discharges and the influx of runoff during periods of floods following the increase of the leaching in coincidence with the agricultural season where soils are rich in nitrogen-based products.

To remedy these problems, we recommend that wastewater discharges be treated before arriving at the Grou River and that a watershed management and sustainable management plan be put in place. And it must be borne in mind that any pollution of its surface waters, no matter how small, will have serious consequences, and will be a real crime for the region.

\section{Thanks}

This study is part of the scientific research, is the result of a collaborative work between the University Mohammed V, Rabat (Faculty of Science \& Scientific institute) and National Institute of Hygiene, Rabat, Morocco.

My heartfelt thanks to the entire research team and to those who have improved this manuscript.

\section{References}

1. M.L. Mc Kinney, Urbaization, biodiversity and conservation. Biosci., 52 (2002) 883-890.

2. R.M. Mulliss, D.M. Revitt, R.B.E. Shutes, Water Sci. Technol., 36 (1997) 195-199.

3. G.A.JR. Burton, R.E. Pitt, Stormwater effects handbook, a toolbox for watershed managers, scientists, and engineers. CRC/Lewis Publishers. (2001) 875.

4. A. Chahlaoui, P. Cugny, S. Lek, A. Zaid, M. Ramdani, Bulletin de la Société d'Histoire Naturelle. Toulouse, 133 (1997) 71-76.

5. J. El Addouli, A. Chahlaoui, A. Berrahou, A. Chafi, A. Ennabili, Approche de la qualité biologique de l'oued Ouislane, au voisinage des effluents bruts de la région de Meknes. Larhyss Journal 09 (2011) 21-33.

6. A. Qninba, M.A. El Agbani, M. Dakki, A. Ben Houssa, Bull. Inst. Sci. 12 (1988) 149156.

7. AFNOR., Qualité de l'eau. Recueil des Normes Françaises Environnement. Tomes 1, 2, 3 et 4. (1997) 1372.

8. J. Rodier, L'analyse de l'eau naturelle, eaux résiduaires, eau de mer, 8ème Edition, Dunod, Paris, (1996) 1383.

9. A. Brahimi, A. Chafi, J. Mater. Environ. Sci. 5 (2014) 1671-1682.

10. N.M. Norme Marocaine de qualité des eaux. Bull. Off. $\mathrm{n}^{\circ} 5062$ (2002).

11. L. Karrouch, A. Chahlaoui. Bio-évaluation de la qualité des eaux de l'Oued Boufekrane (Meknes, Maroc). Biomatec Echo 3 (2009) 6-17.

12. JM. Anderson, Influences of $\mathrm{pH}$ on release of phosphorus from lake sediments. Arch. Hydrobiol. 76 (1975) 411-419.

13. J. Rodier, Analyse de l'eau : eaux naturelles, eaux résiduaires, eau de mer. 7éme édition, Dunot, Paris (1984).

14. A. Ben Moussa, A. Chahlaoui, El.H. Rour, J. Biol Chem. Sc. 6 (2012) 7096-7111.

15. M. Touabay, N. Aouad, J. Mathieu, Ann Limnol 38 ( 2002) 65-80.

16. H. Lamrani, A. Chahlaoui, J. El Addouli, A. Ennabili, Science Lib. 3 (2011) 111-112.

17. R. Delhi, F. Benzha, A. Hilali, M. Tahiri, A. Kaoukaya, L. Baidder, H. Rhinane, J.P. Hangouet, ScienceLib. 4 (2012) 2111-4706. 
18. S. El Blidi, Rizières du Gharb : Qualité physico-chimique, composition faunistique et évaluation de la contamination métallique des différentes composantes de l'agrosystème. Thèse de doctorat Fac. Sci. Rabat, (2005) 194.

19. M. Makhoukh, M. Sbaa, A. Berrahou, Van M. Clooster, Larhyss Journal, 09 (2011) 149-169.

20. A. Maoui, M. Kherouf, F. Derradji, Afrique science, 07(3) (2011) 49-54.

21. A.D. N'diaye, M.S. Khadijettou Mint, M. Ould sid'Ahmed, M. Ould Kankou, Larhyss Journal, 12 (2013) 71-83.

22. M. El Morhit, M. Fekhaoui, A. Serghini, S. El Blidi, A. El Abidi, A. Yahyaoui, M. Hachimi, Bull. Inst. Sci. 34 (2) (2012) 151-162.

23. F. Zidane, K. Cheggari, J-F. Blais, N. Khlil, P. Drogui, J. Bensaida, J. Mater. Environ. Sci. 3 (2012) 99-108.

24. V. Hatje, Environ. Geol. 44 (2003) 231-239. 